\title{
Peningkatan Hasil Belajar Operasional Spreadsheet Jenis dan Fungsi dengan Rumus Statistik Akuntansi melalui Demonstrasi dan Presentasi
}

\author{
NURBAITI SALPIDA GINAYANTI* \\ SMK Negeri 48 Jakarta \\ nsginayanti@gmail.com
}

\begin{abstract}
The research was purposed to find out the effectiveness of demonstration and presentation models are able to improve study result of students in operating Spreadsheet type and function by statistics in X Accounting 1 in SMKN 48 at Academic Year 2014/2015.

The reasearch was conducted on August-November 2014. The method of the research was Action Research (PTK) which was conducted in two cycles. Demonstration andPresentation were used as learning cycle model. $A$ cycle consisted in three times ofmeetings and in the third meeting was done Post test. The indicators have been achieved by the result of research. As the expectation, in the second cycle, namely the number of students got the highest points was $97,45 \%$ and average value was $80,79 \%$. In conclusion, demonstration and presentation are able to improve students' study result in operating spreadsheet type and function by statistics if it was implemented appropriately in X Accounting 1 in SMKN 48 Jakarta.
\end{abstract}

Keywords : Demonstration, Presentation, Spreadsheet 


\section{PENDAHULUAN}

Mata pelajaran "Mengoperasikan Paket Program Pengolah Angka / Spreadsheet, materi jenis dan Fungsi Rumus Statistik merupakan mata pelajaran produktip akuntansi kompetensi keahlian akutansi di SMK bisnis manajemen, oleh karena itu materi pelajaran akuntansi ini sangatlah

kompleks, sementara waktu yang disediakan setiap minggunya terasa berkurang perminggu.

Sesuai dengan standar kompetensi di kelas XAK 1 merupakan salah satu materi pelajaran yang harus disampaikan adalah" Mengoperasikan Paket Program Pengolah Angka / Spreadsheet".

Dalam rangka pelaksanaan 8 Standar Nasional Pendidikan Tentang Standar Kompetensi Kelulusan untuk SMK Negeri 48 Jakarta,Kompetensi keahlian akuntansi dalam rangka memenuhi dunia kerja yang diserap pada dunia usaha / dunia industri, perlu adanya pengembangan diri dalam bidang pemahaman pelajaran akuntansi dalam kelompok mata pelajaran produktif akuntansi yaitu mampu dalam mengoperasikan paket program pengolah angka / spreadsheet yang dapat membuat pembelajaran sebagai pembentukan kepribadian diri bagi siswa akuntansi

.Untuk itu peneliti sebagai guru bidang studi akuntansi merasa tergerak untuk mengembangkan diri siswa dalam bidang kemampuan pembentukan kepribadian seorang akuntan.

SMK Negeri 48 Jakarta perlu mempersiapkan ilmu serta dan mengkondisikan selalu mengoftimalkan Siswa Akuntansi kelas X AK 1 untuk menyiapkan siswa dalam mengikuti praktek kerja industri kelak dikelas selanjutnya nantisehingga dapat menyesuaikan diri dengan Profil dan Karakteristik yang telah diterapkan yaitu ; Menyiapkan siswa akuntansi sesuai standar kebutuhan berdasarkan jumlah dan kwalifikasi baik.

Untuk menggunakan software program pengolah angka (Spreadsheet), guru harus memastikan bahwa sistem operasi dan aplikasi spreadsheet yang dibutuhkan sudah terinstal pada hardware (komputer) yang akan digunakan.

Dalam pembelajaran, guru dan siswa masing-masing mempunyai peranan yang penting dalam rangka pencapaian tujuan pembelajaran, dimana siswa dalam proses pembelajaran harus aktif agar tujuan pembelajaran dapat tercapai, mata pelajaran Akuntansi, tidak terlepas dari kurikulum yang dikembangkan oleh sekolah yakni Kurikulum Tahun 2013 yang berpedoman kepada Peraturan Pemerintah No 19 tahun 2005 tentang Standar Nasional Pendidikan bahwa standar proses pembelajaran pada satuan pendidikan diselenggarakan secara interaktif, inspiratif, menyenangkan, menantang, dan memotivasi siswa untuk berpartisipasi aktif, serta memberi ruang yang cukup bagi siswa untuk dapat menuangkan prakarsa, kreativitas, dan kemandirian sesuai dengan bakat, minat, dan perkembangan fisik serta psikologis siswa.

Prestasi Akademik siswa rendah yakni antara $60 \%$ sampai $70 \%$ yang menguasai konsep. Dengan Model Pembelajaran Demostrasi dan Presentasi, diharapkan akan 
meningkat kan hasil belajar siswa kelas X AK 1.

Nilai hasil belajar mata pelajaran produktif di kelas X AK.1. rendah yaitu rata-rata $60 \%$ dibawah KKM,_adapun KKM Mata Pelajaran Akuntansi ini pada sekolah Peneliti adalah 76 karena sekolah SMK Negeri 48 Jakarta, alternative lainnya dengan melakukan inovasi dan pendekatan pembelajaran, baik dalam menggunakan media ataupun metode penyampaian pembelajaran ini.

Tidak efektifnya pembelajaran Materi Pelajaran Produktif Akuntansi tersebut, namun Peneliti sadar, bahwa pembelajaran selama ini belum menggunakan metode dan model pembelajaran yang bervariasi dalam meningkatkan hasil belajar Siswa Kelas X AK 1.

Tujuan dalam pembelajaran pada dasarnya merupakan rumusan tingkah laku dan kemampuankemampuan yang harus dicapai dan dimiliki para siswa setelah menyelesaikan kegiatan belajar dalam proses belajar mengajar

Berdasarkan masalah diatas, maka Peneliti akan melakukan Penelitian Tindakan Kelas dengan menerapkan Model Pembelajaran Demonstrasi dan Presentasi dalam pembelajaran Mata Pelajaran Produktif Akuntansi dengan Mengoperasikan Paket Program Pengolah Angka (Spreadsheet) melalui materi jenis dan Fungsi rumus statistikdi kelas $\mathrm{X}$ AK 1 , SMK Negeri 48 Jakarta.

\section{Rumusan Masalah}

Masalah dalam penelitian ini adalah sebagai berikut Apakah penggunaan model pembelajaran Demonstrasidan Presentasi dapat meningkatkan prestasi hasil belajar siswa pada Pembelajaran Akuntansi Keuangan Mengoperasikan Paket Program Pengolah Angka / Spreadsheet di kelas X AK1 dengan materi Jenis dan Fungsi rumus statistik Kopetensi Keahlian Akuntansi pada SMK Negeri 48 Jakarta pada Semester Ganjil Tahun 2014/ 2015.

\section{Tujuan Penelitian}

Tujuan yang ingin dicapai dalam penelitian tindakan kelas ini adalah Untuk mengetahui efektifitas penggunaan model pembelajaran Demonstrasi dan Presentasi dalam Meningkatkan Prestasi Hasil Belajar siswa pada Mata Pelajaran Produktif Akuntansi , khususnya tentang materi Mengoperasikan

Paket Program Pengolah Angka/ Spreadsheet dengan materi jenis dan fungsi rumus statistik di Kelas $X$ AK 1 Akuntansi Kopetensi Keahlian Akuntansi pada Semester Ganjil Tahun 2014/2015 di SMK Negeri 48 Jakarta.

\section{DESKRIPSI TEORITIS}

\section{A. Hasil Belajar}

Hasil dimana guru melihat bentuk akhir dari pengalaman interaksi edukatif yang diperhatikan adalah penempatan tingkah laku (Surakhmad, 1982), Hasil belajar merupakan hasil dari proses kompleks, hal ini disebabkan banyak faktor yang terkandung didalamnyabaik internal maupun eksternal.

$$
\text { Manusia mengadakan }
$$
interaksi dengan dunia luar dengan menggunakan simbol-simbol. Kemampuan belajar cara inilah yang disebut "kemampuan Strategi Kognitif". Ini merupakan organisasi keterampilan yang internal (internal 
organized skill) yang perlu untuk belajar mengingat dan berpikir. Kemampuan ini berbeda dengan kemampuan intelektual, karena ditujukan ke dunia luar, dan tidak dapat dipelajari hanya dengan berbuat satu kali serta memerlukan perbaikan - perbaikan secara terus menerus. Kemampuan ini belajan tidak akan berhasil dengan baik.

\section{B. Prestasi Belajar}

Proses belajar yang dialami oleh siswa menghasilkan perubahanperubahan: dalam bidang pengetahuan atau pemahaman, dalam bidang keterampilan, dalam bidang nilai, dan sikap.

Adanya perubahan itu tampak dalam prestasi belajar yang dihasilkan oleh siswa terhadap pertanyaan, persoalan, tugas yang diberikan oleh guru.

\section{Hakekat Pembelajaran}

Pembelajaran Produktif Akuntansi dengan standar kompetensi Mengoperasikan Paket Program Pengolah Angka / Spreadsheet, dengan materi jenis dan fungsi rumus statistik, merupakan kelompok mata pelajaran produktipfakuntansi keuangan ini merupakan bagian dari ilmu yang memiliki karakteristik pemahaman yang sama dengan kopetensi keahlian produktif akuntansi keuangan lainnya.

Oleh karena itu, para Akuntan harus mampu melakukan kerja ilmiah dalam menyelesaikan masalah atau mencari jawaban permasalahan permasalahan yang dihadapi.

\section{Pembelajaran Demonstrasi dan Presentasi}

$$
\text { Model }
$$

Demonstrasi

pembelajaran

dikembangkan untuk mencapai tujuan penting pembelajaran, yaitu hasil belajar akademik, penerimaan terhadap keragaman, dan pengembangan keterampilan sosial .

Pembelajaran Demonstrasi dan Presentasi, merupakan model pembelajaran dengan siswa bekerja dalam kelompok yang memiliki kemampuan heterogen, untuk mendemonstrasikan materi yang diajarkan saat itu.

Pembelajaran Demontrasi dan Presentasi sebagai sekumpulan strategi mengajar yang digunakan guru agar siswa saling membantu dalam mempelajari sesuatu. Dan mempresentasikan dihadapan kelompok.

Pembelajaran

Model

Demonstrasi dan Presentasi dilaksanakan mengikuti tahap-tahap sebagai berikut :
a. Menyampaikan tujuan pembelajaran dan perlengkapan pembelajaran.
b. Menyampaikan informasi
c. Mengorganisasikan siswa ke dalam kelompok-kelompok belajar
d. Membantu siswa belajar dan bekerja dalam kelompok.
e. Evaluasi atau memberikan umpan balik.
f. Memberikan penghargaan
g. Mendemonstrasikan Mempresentasikan

\section{E. Tujuan Pembelajaran Demonstrasi dan Presentasi}

Tiga tujuan pembelajaran emonstrasi dan presentasi sebagai berikut :

1. Meningkatkan kinerja siswa dalam tugas-tugas akademik. Beberapa ahli berpendapat bahwa model ini unggul dalam membantu siswa memahami konsep - konsep yang sulit dalam angka-angka bidang keuangan .

2. Penerimaan yang luas terhadap

Orang yang berbeda


menurut ras, budaya, kelas social kemampuan maupun ketidakmampuan. Mengajarkan untuk saling menghargai satu sama lain.

3. Mengajarkan kepada siswa keterampilan kerjasama dan kolaborasi. Kemampuan ini penting karena banyak anak muda dan orang dewasa masih kurang dalam keterampilan komputer.

\section{F. Kemampuan Pembelajaran Model Demontrasi dan Presentasi}

Melalui model ini diharapkan tidak cuma kemampuan akademik yang dimiliki siswa tetapi juga ketrampilan yang lain. Keterampilan-keterampilan itu antara lain:

1. Keterampilan - keterampilan komputer keuangan.

2. Keterampilan sosial dan berbagi

3. Keterampilan berperan serta

4. Keterampilan - keterampilan. Komunikasi

5. Pembangunan tim

6. Keterampilan - keterampilan kelompok. yang lain di jurusan. Model Demonstrasi dan Presentasi merupakan menunjukan dengan nyata yaitu tehnik yang dikembangkan untuk memberi siswa kesempatan untuk bekerja sendiri serta bekerja sama dengan orang lain. Keunggulan dan tehnik ini adalah optimalisasi partisipasi siswa, yaitu memberi kesempatan delapan kali lebih banyak kepada setiap siswa untuk dikenali dan menunjukkan partisipasi mereka kepada orang lain.

Strategi simulasi yang digunakan oleh para guru menerapkan langkah-langkah sebagai berikut:

Tahap-1: Thinking (berfikir)

Tahap-2: Pairing
Tahap-3: Sharing

Kelebihan model pembelajaran Demonstrasi dan Presentasi adalah:

1. Memungkinkan siswa untuk merumuskan dan mengajukan pertanyaan-pertanyaan mengenai materi yang diajarkan, karena secara tidak langsung memperoleh contoh pertanyaan yang diajukan oleh guru, serta memperoleh kesempatan untuk memikirkan materi yang diajarkan dan mendemonstrasikan serta mempresentasikan

2. Siswa akan terlatih menerapkan konsep karena bertukar pendapat dan pemikiran dengan temannya untuk mendapatkan kesepakatan dalam memecahkan masalah.

3. Siswa lebih aktif dalam pembelajaran karena menyelesaikan tugasnya dalam kelompok, dimana tiap kelompok hanya terdiri dari 2 orang,

4. Siswa memperoleh kesempatan untuk mendemonstrasikan mempersentasikan hasil diskusinya dengan seluruh siswa sehingga ide yangada menyebar,

5. Memungkinkan guru untuk lebih banyak memantau siswa dalam proses pembelajaran.

Kelebihan pembelajaran Demonstrasi adalah sebagai berikut

1. Membantu siswa untuk respek pada orang lain dan menyadari akan segala keterbatasannya serta menerima segala perbedaan.

2. Siswa dapat mengembangkan kemampuan untuk menguji ide dan pemahamannya sendiri dan menerima umpan balik.

3. Interaksi yang terjadi selama pembelajaran dapat meningkatkan motivasi dan member rangsangan untuk berpikir sehingga bermanfaat bagi proses pendidikan jangka panjang. 
4. Pembelajaran model Demonstrasi dan Presentasi bias mengajarkan orang untuk bersama-sama dan lebih efisien, biasanya kegiatan praktikperlu dilakukan dalam jangka waktu tertentu. Dengan bekerja sama, dua orang dapat menyelesaikan sesuatu lebih cepat.)

\section{G. Hipotensis Tindakan}

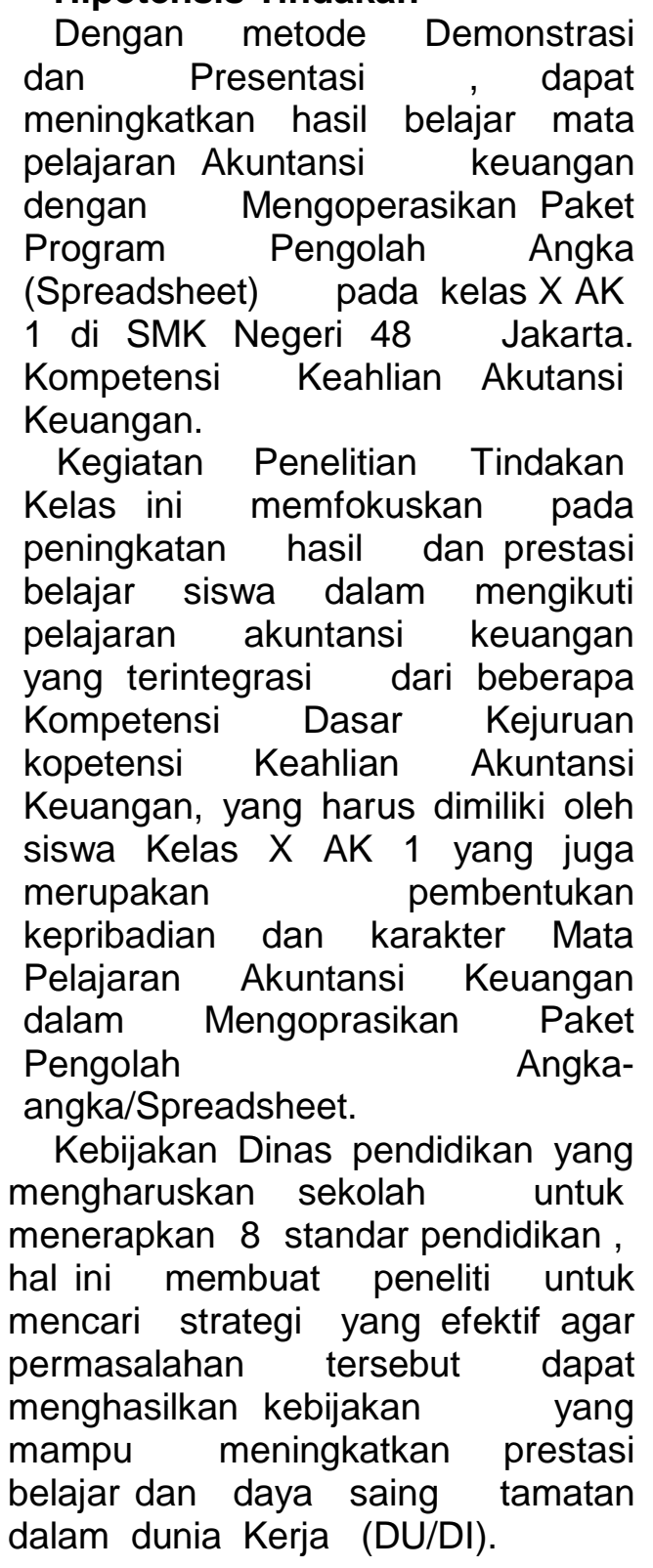

\section{METODE PENELITIAN}

\section{Setting Penelitian}

Lokasi Penelitian : SMK Negeri 48 Jakarta.

Subyek Penelitian : Siswa Kelas

X AK 1 , sebanyak 35 siswa

Waktu Penelitian: 6 Bulan Juli s/d Desember 2014.

\section{Prosedur Penelitian}

Dalam penelitian ini dilakukan dua siklus dan tiap siklus tiga pertemuan Pelaksanaan Tindakan :

Presentasi dapat digunakan / diteruskan sebagai model pembelajaran disekolah.

Tehnik Pengumpulan Data. Pengumpulan data dilaksanakan melalui tahapan sebagai berikut:

Studi dokumen berupa hasil kinerja siswa tiap kelompok, Observasi terhadap aktivitas dikelas X AK 1. SMK Negeri 48 Jakarta, pada saat pembelajaran Akuntansi Keuangan Mengoprasikan Paket program Pengolahan Angka Spreadsheet, materi jenis dan fungsi rumus statistik, selama berlangsung PTK pada siklus 1 maupun 2 .

Observasi meliputi : kedisiplinan, minat belajar, aktifitas dikelas, mendengar pendapat teman.

Evaluasi hasil belajar / ulangan harian sebelum dan selama berlangsung PTK dalam siklus 1 dan Siklus 2.

\section{DEKRIPSI HASIL PENELITIAN}

Aktifitas / penilaian kinerja siswa dalam diskusi kelompok. Penilaian kinerja siswa / aktifitas siswa dalam hal menyelesaikan tugas kelompok selama proses. Kebiasaan siswa yang akan diperhatikan pada penelitian ini cenderung kepada kebiasaan siswa 
yang bersifat negative. Siswa yang tidak semangat pada saat proses pembelajaran akan melakukan.

Dari observasi kebiasaan negative siswa pada siklus pertama,diperoleh gambaran kebiasaan negative siswa menonjol pada kebiasaan ngobrol/mengganggu teman dan jalan-jalan ke kelompok lain pada saat diskusi atau proses belajar berlangsung. Pada pertemuan pertama siswa yang ngobrol ada 10 orang, jalan ke kelompok lain ada 4 orang, diam saja ada 4 orang, purapura sibuk 2 orang, sedangkan yang main HP tidak ada satu orangpun. Jumlah siswa yang melazkukan kebiasaan negative ini tidak terlalu banyak,hanya kurang lebih 6,15\% saja dari total jumlah siswa NilaiPost test Siswa.

\section{Refleksi Siklus 1}

Dari hasil observasi pada siklus , peneliti menemukan keberhasilan dan kegagalan dari tindakan yang diberikan, pada tahap awal pembelajaran masih ada siswa yang tidak perhatianterhadap proses pembelajaran, yaitu adanya siswa yang ngobrol dan jalan-jalan ke kelompok lain, tetapi setelah diberi pengertian bahwa setiap siswa harus aktif menjawab pertanyaan dalam LKS maka pada pertemuan kedua mereka sudah tidak melakukannya lagi .

Kehadiran siswa dalam mengikut proses pembelajaran sangat baik, hanya ada dua orang tidak masuk karena sakit, jadi mereka mempunyai kemauan yang baik untuk mengikuti pelajaran di kelas.

Dari aspek-aspek yang diamati, pelaksanaan pembelajaran belum mencapai indikator yang diharapkan, nilai rata-rata post testsiswa padasiklus pertama ini hanya 78,28 dan siswa yang mencapai nilai batas penting atau materi essensial yang harus dipahami oleh para siswa dan mengoptimalkan tanya jawab serta memberi perhatian yang lebih kepada siswa yang kurang aktif.

sedikit yang melakukan kebiasaan negative, yakni hanya 0,77\%. Hal ini disebabkan karena mereka sadar bahwa nilai post test pada siklus 1 sebagian besar tidak tuntas, tampaknya merekasadar betul bahwa dalam belajar perlu konsentrasi dan usaha yang sungguh-sungguh.

\section{Refleksi Siklus 2}

Pada siklus ke 2 ini peneliti melihat bahwa pelaksanaan model pembelajaran

Demostrasi dan Presentasi telah dapat meningkatkan prestasi belajar siswa, dan mencapai indikator penelitian yang ditetapkan yakni persentase siswa yang mencapainilai tuntas adalah $100 \%$, persentase rata-rata siswa yang aktif melakukan diskusi dalam proses pembelajaran lebih dari $90 \%$ dan yang melakukan kebiasaan negative kurang dari 10\%.Dengan demikian dapat dikatakan bahwa pelaksanaan pembelajaran dengan Model Demonstrasi dan Presentasi dapat meningkatkan prestasi belajar siswa.

Berikut ini adalah data hasil penelitian dari semua siklus yang akan dianalisis 


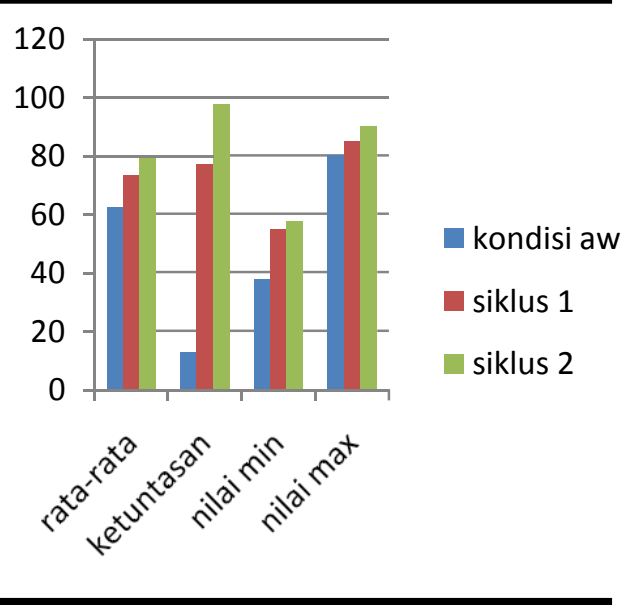
pada

Tindakan yang diberikan

Pembelajaran dengan model

Demonstrasi dan presentasi dengan memberikan penguatan oleh peneliti pada siklus 2 telah dapat meningkatkan prestasi belajar Mata Pelajaran Akuntansi dan Keuangan. Diharapkan dalam penelitian ini, siswa yang melakukan kegiatan negatif pun tidak melebihi persentase $15 \%$ tetapi hanya $0,67 \%$. Pada siklus 2 ini dapat dikatakan bahwa prestasi Belajar siswa telah meningkat.

\section{KESIMPULAN}

Berdasarkan semua uraian diatas khususnya uraian pada Bab IV Peneliti dapat membuat kesimpulan sebagai berikut:

Presentasi dapat meningkatkan prestasi belajar Akuntansi Keuangan dalam aspek pemahaman konsep. Mengoperasikan Program Angka Spreadsheet.

Aspek yang kedua adalah keaktifan siswa mengikuti proses pembelajaran meningkat dari 30 yang aktif menjadi 35 orang. Aspek yang terakhir adalah kebiasaan negative siswa berkurang dari $5 \%$ menjadi $0 \%$ Dengan demikian model pembelajaran Demonstrasi dan Presentasi ini selain dapat meningkatkan prestasi nilai hasil belajar juga dapat mendorong siswa untuk meningkatkan aktivitas pembelajaran yang positif dan menurunkan kebiasaan buruk pada saat proses pembelajaran.

\section{SARAN}

Berdasarkan hasil penelitian, tindakan yang diberikan dalam pembelajaran Model Demonstrasi dan Presentasi dapat meningkatkan prestasi belajar kopetensi keahliah Akuntansi keuangan bagi siswa. Disarankan kepada para guru agar lebih jeli dalam menentukan rencana tindakan yang diberikan sehingga tindakan yang diberikan tidak menimbulkan masalah baru dan membuat siswa meningkat hasil belajar.

\section{DAFTAR PUSTAKA}

Surakhmad, W. (1982). Pengantar Interaksi mengajar Belajar Dasar dan Teknik Metodologi Pengajaran. Bandung : Tarsito. 